\title{
Effect of Hydraulic Retention Time (HRT) and Organic Loading Rate (OLR) to the Nata de coco Anaerobic Treatment Eficiency and its Wastewater Characteristics
}

\author{
Istna Nafi Azzahrani, Fanny Arivia Davanti, Ria Millati, Muhammad Nur Cahyanto* \\ Department of Food and Agricultural Product Technology, Faculty of Agricultural Technology, \\ Universitas Gadjah Mada, Jl. Flora No. 1, Bulaksumur, Yogyakarta 55281, Indonesia \\ Email: mn_cahyanto@ugm.ac.id
}

Submission: April 20, 2017; Acceptance: February 5, 2018

\begin{abstract}
In this study, experiments were conducted to investigate the effect of hydraulic retention time (HRT) and organic loading rate (OLR) on process stability of nata de coco wastewater anaerobic treatment using semi-continuous digester. The standard-rate anaerobic digester with working volume of $8.5 \mathrm{~L}$ was used to investigate the effect of three different hydraulic retention times (15, 20, and 25 days), and a standard-rate anaerobic digester with working volume of $9.1 \mathrm{~L}$ was operated at different organic loading rates of $0.5,1$, and $1.5 \mathrm{~g} / \mathrm{L} / \mathrm{day}$. The findings revealed that minimum HRT for nata de coco wastewater anaerobic treatment using semi-continuous digester was achieved at HRT 20 days. Based on data from this study, the reduction of organic content in nata de coco wastewater increased when OLR increased until $1 \mathrm{~g} / \mathrm{L} /$ day. But then those parameters value decreased when OLR being increased further to 1.5 $\mathrm{g} / \mathrm{L} /$ day. It showed that at $1.5 \mathrm{~g} / \mathrm{L} /$ day the amount of substrate fed to the system was exceeding the total degradation capacity of methanogenic microorganisms, hence the organic overload happened and decreased the efficiency of organic content reduction in anaerobic treatment of nata de coco wastewater.
\end{abstract}

Keywords: Anaerobic; hydraulic retention time; nata de coco; organic loading rate

\section{INTRODUCTION}

Nata de coco is one of the products widely produced in Yogyakarta Special Region (DIY). There are at least, 150 nata de coco producers in Central Java Province and Yogyakarta Special Region, and $40 \%$ of national nata de coco production is produced from these two provinces (Ika, 2015). Nata de coco industry in Banguntapan, DIY processes $\pm 5,509 \mathrm{~kg}$ nata/day (Nayenggita, 2016). The growth of nata de coco agroindustry number causes an increase of waste produced by the industry (Hakimi \& Budiman, 2006). Based on a field observation, the liquid waste from nata de coco processing in DIY is simply collected in a sedimentation pool to be dumped later into rice-field irrigation ditches, without any further processing.

Based on Nayenggita (2016), the characteristics of nata de coco waste show varying COD concentrations from $2,300 \mathrm{mg} / \mathrm{L}$ to $9,800 \mathrm{mg} / \mathrm{L}$, depending on the process it went through. The Quality Standards of Coconut Processing Waste Water according to the Minister of the Environment's Regulation No. 5 (2014) shows that maximum COD concentration allowed is 150 $\mathrm{mg} / \mathrm{L}$. If compared with the test results, the quality standards show that nata de coco liquid waste does not meet the standards. Therefore, a waste processing is needed to reduce the burden of pollutants.
Biological waste processing can degrade organic compound contained in the waste, so that the bad smell caused by organic compound in the waste can be reduced. The high content of organic compound in the waste can be reduced either aerobically or anaerobically. The cost of aerobic waste processing is high, because it needs a lot of oxygen supply. Whereas the cost of anaerobic processing is lower because it uses anaerobic bacteria to degrade the organic content in the waste. Anaerobic bacteria do not need oxygen, therefore, anaerobic processing is known as the process that can lower BOD and COD contents effectively at a low cost (De Mes et al., 2003; Demirer et al., 2000; Okoh et al., 2007).

In anaerobic processing, there are factors that influence its effectiveness, namely $\mathrm{pH}$, temperature, hydraulic retention time (HRT), and organic loading rate (OLR). HRT is the average time the waste remains in the reactor. Too little HRT does not allow enough time for anaerobic microbes to multiply, and microbial concentration will decrease and it will wash out of the reactor (Drosg, 2013). OLR is the amount of organic content added into the reactor per reactor unit volume $\left(\mathrm{kg} \mathrm{VS} / \mathrm{m}^{3} /\right.$ day or $\mathrm{kg} \mathrm{COD} / \mathrm{m}^{3} /$ day). Throughout the process, usually OLR is slowly increased towards desired condition to allow the microbes to adapt to operation environment. OLR in anaerobic waste processing needs 
to be regulated because if it is too high, it can cause organic overload and acidification (Drosg, 2013).

In this research, we investigate characteristics of nata de coco industry waste, and the influence of $10 ; 15$; and 25 day HRT and 0.5; 1.0; and $1.5 \mathrm{~g}$ OLR COD/L/day in anaerobic processing efficiency of nata de coco liquid waste.

\section{RESEARCH METHOD}

Nata de coco liquid waste was obtained from nata de coco cutting and washing process waste at a nata de coco production factory in DIY. The liquid waste was characterized (Table 1) as follows:

Table 1. Characteristics of nata de coco liquid waste in HRT research

\begin{tabular}{cc}
\hline Parameter & Amount \\
\hline COD $(\mathrm{mg} / \mathrm{L})$ & 12,170 \\
BOD $(\mathrm{mg} / \mathrm{L})$ & 10,440 \\
TSS Influent $(\mathrm{mg} / \mathrm{L})$ & 640 \\
pH Influent & 4.17 \\
\hline
\end{tabular}

Inoculum for anaerobic process was obtained from cow dung biogas process effluent at Agro-Technology Information Center (PIAT) UGM, Yogyakarta. Chemical reagents used were: concentrated sulfuric acid (Merck, 96.1\%); $\mathrm{Fe}\left(\mathrm{NH}_{4}\right)\left(\mathrm{SO}_{4}\right)_{2} ; \mathrm{K}_{2} \mathrm{Cr}_{2} \mathrm{O}_{7} ; \mathrm{Ag}_{2} \mathrm{SO}_{4}$ in $\mathrm{H}_{2} \mathrm{SO}_{4}$; and ferroin indicator.

\section{Anaerobic Digestion of Liquid Waste}

The digester used was anaerobic tank ordered from CV. Glass Blower Gejayan, Yogyakarta. An empty digester was connected to a gas counter using a clear plastic hose and hose connectors. Effluent container was placed right under the effluent pipe and a biogas containing balloon was connected to the gas counter using a clear plastic hose and hose-connectors as seen in Figure 1. After the digester was correctly installed, the digester was filled with inoculum which came from cow dung biogas processing effluent from PIAT UGM, Yogyakarta and left until biogas production stopped. This was meant to ensure inoculum stabilization. According to a study, stabilization before operational needs to be performed especially when operational temperature is lower than 45 ${ }^{\circ} \mathrm{C}$ and higher than $50{ }^{\circ} \mathrm{C}$ (Kim et al., 2006).

In the research with $\mathrm{HRT}$, three variations were performed, namely 15; 20; and 25 days, whereas for OLR variations, HRT was set at 20 days. The HRT setting was done with the previous experiment on 3 HRT variations:
15; 20; and 25 days, using nata de coco liquid waste with a COD value of $12,170 \mathrm{mg} / \mathrm{L}$. From the experiment, the results showed that each HRT had COD Removal Efficiency of $34.35 \% ; 90.24 \%$; and $75.2 \%$, respectively. HRT 20 was finally chosen to be used in this research based on the consideration of time spent with high COD removal.

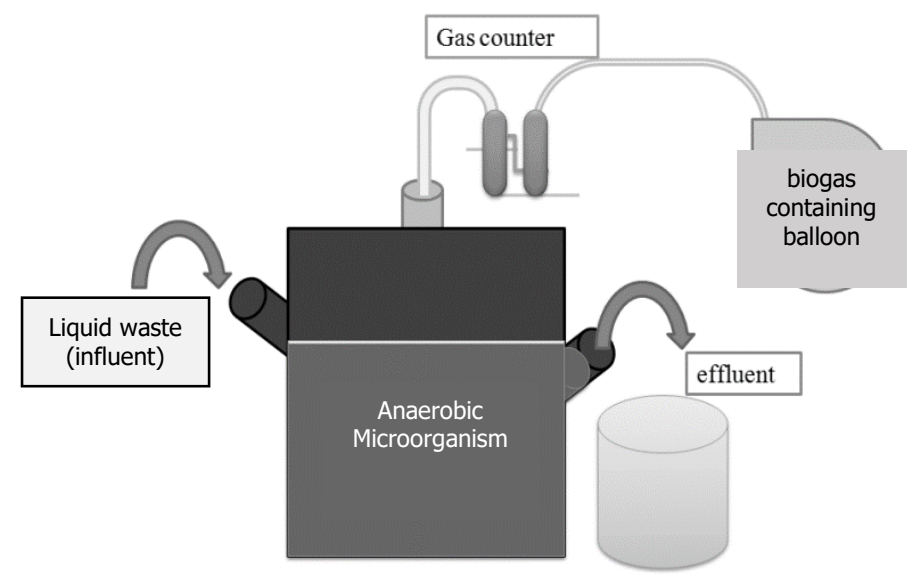

Figure 1. Anaerobic liquid waste processing scheme

Processing with HRT variations started from the longest HRT period, that is, 25 days, and then slowly lowered to 20-day period, and finally, to 15-day period. Whereas for OLR variations, it started with the least value of OLR, that was, $0.5 \mathrm{~g} / \mathrm{L} /$ day, and then consecutively increased to $1 \mathrm{~g} / \mathrm{L} /$ day, and finally 1.5 $\mathrm{g} / \mathrm{L} / \mathrm{day}$, when the process was stably running.

The process is considered stable when the increase of effluent COD has reached $10 \%$ (Lestari et al., 2012). This is meant to avoid shock loading, and to ensure that microbes can adapt with the system's environment (Drosg, 2013). Before feeding, influent which was going to be entered was analyzed for its characteristics. Influent addition was performed 3 times a day at the same time every day. The effluent produced was later analyzed for its characteristics. Each of the influent and affluent were tested for COD; TSS; and $\mathrm{pH}$, whereas for $B O D$, the test was only performed at the beginning and at the end of HRT and OLR variation periods.

\section{Analysis Method}

\section{Biochemical oxygen demand (BOD) analysis}

BOD analysis was performed to determine the amount of oxygen needed to oxidize organic compounds in the waste water with the help of microbes in a certain environmental condition based on SNI 6989.72:2009

Table 2. Experiment design with HRT and OLR variations

\begin{tabular}{cccccc}
\hline Volume & $\begin{array}{c}\text { Hydraulic Retention } \\
\text { Time (HRT) Variation }\end{array}$ & $\begin{array}{c}\text { Waste input being } \\
\text { inserted }\end{array}$ & $\begin{array}{c}\text { Organic Loading } \\
\text { Rate } \\
\text { (OLR) Variation }\end{array}$ & $\begin{array}{c}\text { Debit } \\
(\mathrm{L} / \mathrm{days})\end{array}$ & $\begin{array}{c}\text { COD } \\
(\mathrm{mg} / \mathrm{L})\end{array}$ \\
\hline \multirow{3}{*}{$8.5 \mathrm{~L}$} & 25 days & 0.34 L/days & $0.5 \mathrm{~g} / \mathrm{L} /$ days & 0.455 & 10.000 \\
& 20 days & 0.42 L/days & $1.0 \mathrm{~g} / \mathrm{L} /$ days & 0.455 & 20.000 \\
15 days & 0.56 L/days & $1.5 \mathrm{~g} / \mathrm{L} /$ days & 0.455 & 30.000 \\
\hline
\end{tabular}


(Badan Standardisasi Nasional, 2009). Sample was diluted with a certain dilution factor using a nutrition solution. The dilution factor depends on the characteristics of sample, dilution selection was made based on expectation that it would have produced dissolved oxygen reduction to at least $2.0 \mathrm{mg} / \mathrm{L}$ and the remaining dissolved oxygen at $1.0 \mathrm{mg} / \mathrm{L}$ after a 5-day incubation. After dilution, samples were mixed and moved to the test bottle. Samples were left for a while and observed whether air bubbles were formed. If bubbles were formed, the test bottle needed to be knocked softly to make the bubbles disappear. The test bottle was then sealed with a rubber cap. Dissolved oxygen in the sample was quickly determined and sample was incubated at a temperature of $20^{\circ} \mathrm{C}$ in a dark room for 5 days. Dissolved oxygen in the sample after 5 days was determined, and BOD value was calculated based on dissolved oxygen before and after incubation, using Equation 1:

$\mathrm{BOD} 5=\left(\frac{\mathrm{mg}}{\mathrm{L}}\right)=\frac{\mathrm{B}}{\mathrm{A}}(\mathrm{C}-\mathrm{D})$

Remarks:

A: Total volume before dilution $(\mathrm{mL})$

B: Sample volume after dilution $(\mathrm{mL})$

C: Initial diluted oxygen content

D: End diluted oxygen content

Determining dissolved oxygen content was performed by adding $2 \mathrm{~mL}$ of $\mathrm{MnSO}_{4}$ solution and $2 \mathrm{~mL}$ of iodine azide solution at the bottom of the test bottle containing 300 $\mathrm{mL}$ sample. The bottle was then sealed, and the content was mixed by turning the bottle upside down and back for at least 15 times. After being left for 2 minutes, the bottle was then opened and $2 \mathrm{~mL}$ thick sulfate acid was added through the wall of the bottle neck. The content was again mixed, and a sample equivalent with $200 \mathrm{~mL}$ initial sample was taken to be titrated with $0.025 \mathrm{~N}$ sodium thiosulfate solution until the color became pale yellow. The content was then added with 1-2 mL starch solution to get titrated again until the blue color disappeared for the first time.

\section{Chemical Oxygen Demand (COD) Analysis}

COD analysis was performed to determine the oxygen amount needed to chemically oxidize organic component, producing $\mathrm{CO}_{2}$ and water. $\mathrm{COD}$ value was analyzed based on Standard Methods 5220C (Rice et al., 2012) on COD analysis using a closed reflux method. $2.5 \mathrm{~mL}$ sample that had been diluted is put into a Hach tube sized $16 \times 100$ $\mathrm{mm}$, after that, $1.5 \mathrm{~mL}$ of $0.0167 \mathrm{M}$ dichromic potassium solution and $3.5 \mathrm{~mL}$ of $\mathrm{Ag}_{2} \mathrm{SO}_{4}$ in $\mathrm{H}_{2} \mathrm{SO}_{4}$ solution were added into the smoke chamber. The tube was then sealed and heated using a heating block at $150^{\circ} \mathrm{C}$ for 2 hours. After the temperature decreased to room temperature, the sample was given 1 drop of ferroin indicator and then titrated using $0.10 \mathrm{M}$ ferrous ammonium sulfate. End of titration was marked with a color change from metallic green to reddish brown. The COD value was calculated according to the following Equation 2:
$\operatorname{COD}(\mathrm{mg} / \mathrm{L})=\frac{(\mathrm{A}-\mathrm{B}) \times \mathrm{M} \times 8000}{\mathrm{~mL} \text { sampel }}$

Remarks:

A: $\mathrm{mL}$ blank titration

B: $\mathrm{mL}$ sample titration

M: ferrous ammonium sulfate molarity

\section{Total suspended solid (TSS) analysis}

TSS analysis was performed based on Standard Methods 2540 (Rice et al., 2012) on Total Suspended Solid (TSS) with a drying temperature of $103-105^{\circ} \mathrm{C}$. Ten (10) $\mathrm{mL}$ of sample was put into a fiber glass, which had been weighed, attached at the vacuum holder. The fiber glass containing suspended solids was then put into a bowl, which had been weighed and put in the oven at $103-105{ }^{\circ} \mathrm{C}$ for 24 hours. TCC was calculated using Equation 3.

Total Suspended Solid $\left(\frac{\mathrm{mg}}{\mathrm{L}}\right)=\frac{(\mathrm{A}-\mathrm{B}) \times 1000}{\mathrm{~mL} \text { sampel }}$

Remarks:

A: filter weight + residue $(\mathrm{mg})$

B: filter weight (mg)

\section{RESULTS AND DISCUSSION}

\section{HRT Effect on Anaerobic Liquid Waste Processing}

\section{Effect of HRT variation on COD parameter reduction}

Based on the results obtained, minimum HRT for anaerobic processing of nata de coco waste was 20 days. In the treatment using a 20-day HRT, COD reduction occurred significantly, that was, $1,200 \mathrm{mg} / \mathrm{L}$ from the initial $12,170 \mathrm{mg} / \mathrm{L}$, or around $90.224 \%$. In shorter HRT, that was, 15 days, COD reduction was inefficient because the value of COD removal was low. This indicates a hydraulic overload. Hydraulic overload happens when HRT period is insufficient that methaneproducing bacteria is unable to produce fast enough, consequently, washout takes place (Gerardi, 2003) because influent amount given exceeds digester's capacity to process organic component.

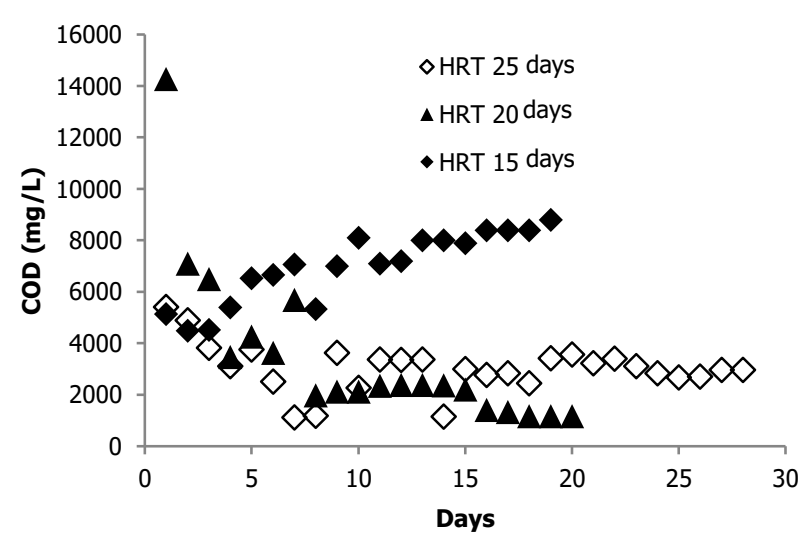

Figure 2. COD removal efficiency dynamics chart in various HRTs 
Table 3. effluent COD test results

\begin{tabular}{cccc}
\hline $\begin{array}{c}\text { HRT } \\
\text { Variation }\end{array}$ & $\begin{array}{c}\text { Influent COD } \\
(\mathrm{mg} / \mathrm{L})\end{array}$ & $\begin{array}{c}\text { Effluent COD } \\
(\mathrm{mg} / \mathrm{L})\end{array}$ & $\begin{array}{c}\text { COD } \\
\text { Removal }(\%)\end{array}$ \\
\hline 15 days & 12,170 & 8,800 & 34.35 \\
20 days & 12,170 & 1,200 & 90.22 \\
25 days & 12,170 & 2,200 & 75.20 \\
\hline
\end{tabular}

Washed out methanogenic bacteria causes volatile fatty acids accumulation because acidic microbes will become dominant in number (Lukitawesa, 2014). This will cause a reduction in gas production by methanogens, and anaerobic process will not run well because COD reduction is not maximum.

In anaerobic processing for 25 days, although the efficiency was quite high, it was not better than the 20day processing. The cause of this needs to be further investigated, especially in relation with the fact that operational temperature condition for 25-day HRT was set far after stabilization was completed.

\section{Effect of HRT Variation on TSS Parameter Reduction}

Before going through processing, TSS content in nata de coco waste was between $560-680 \mathrm{mg} / \mathrm{L}$. According to Gerardi (2003), anaerobic digestion is the best treatment to reduce solids. Suspended solids reduction usually takes between 10-20 days Gerardi (2003). In the results obtained in Figure 3, TSS content reduced significantly. In waste processing with 25-day duration, TSS reduction efficiency was 80.95\%; in waste processing with 20-day duration, TSS reduction efficiency was $61.16 \%$; whereas waste processing with 15 -day duration, TSS reduction efficiency was $67.26 \%$.

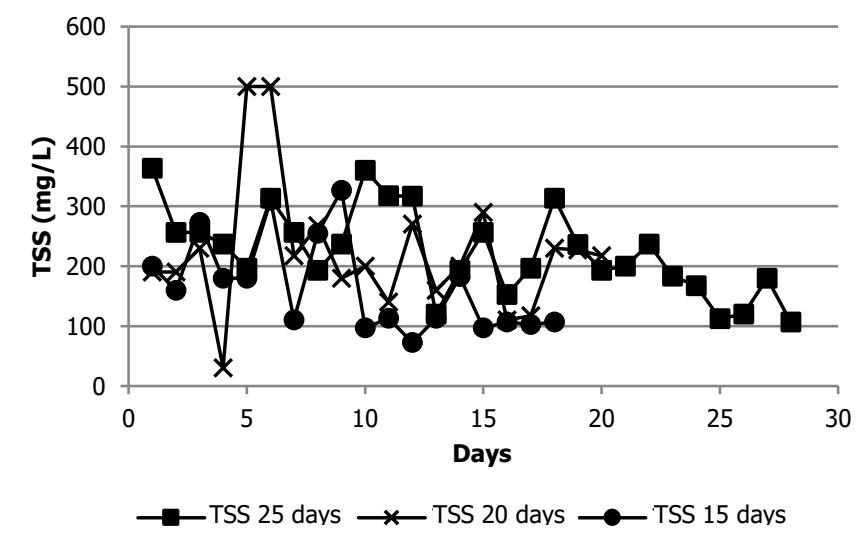

Figure 3. Effect of Hydraulic Removal Time vs TSS

A fluctuation in process efficiency with process duration of 20 and 15 days was obtained. TSS value in 20-days processing was lower compared to the TSS value in 15-days processing. The reason for this could be that every day the waste sample taken contained different amount of solids. But from the results obtained, it can be concluded that a 15-day processing time was sufficient to reduce TSS value, because the reduction was significant.

\section{Effect of HRT on pH change}

Methanogenic bacteria works in $\mathrm{pH}$ range between 68 , and they are the bacteria with the most defining role in anaerobic processing success because methaneforming bacteria are strict anaerobs and die quickly (Gerardi, 2003). This means that effluent of anaerobic process should be around the $\mathrm{pH}$ range above.

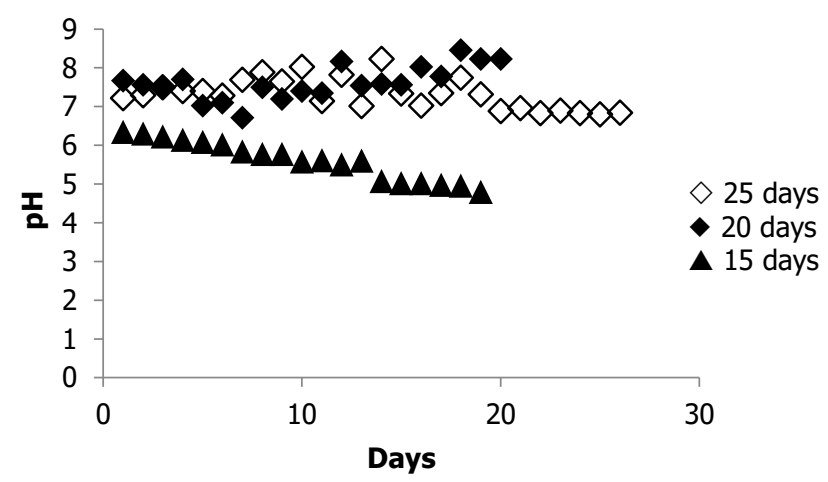

Figure 4. Dynamics of $\mathrm{pH}$ in various HRT

From Figure 4, it can be seen that nata de coco waste processing with a retention time of 20 and 25 days, effluent $\mathrm{pH}$ remained at a range between $6-8$. Whereas in the waste processing with a 15-day retention time, effluent $\mathrm{pH}$ was quite low reaching 4.8. This result was similar with the low COD removal value at the longest cycle of 15-day retention time, which indicated that anaerobic digestion did not run well. This $\mathrm{pH}$ change is related with volatile acids content throughout the process, in which acetic acid will dominate two thirds in the the methane forming phase (Liu \& Whitman, 2008). Based on a research conducted by Lukitawesa (2014), when organic loading applied to a system is too high, the concentration of volatile fatty acids will increase. Volatile fatty acids such as acetate, propionate and butyrate will dominate, and cause a reduction in the amount of methanogenic bacteria, and less biogas will be produced. Therefore, a 15-day HRT can indicate that processing time was not long enough, which caused a washout of methanogenic bacteria and produced low $\mathrm{pH}$.

\section{Effect of HRT Variation on BOD Parameter Reduction}

Table 4 shows the result of final effluent test on nata de coco waste at HRT 15; 20; and 25.

Table 4. Comparison $\mathrm{BOD}_{5}$ values of final effluent of nata de coco waste

\begin{tabular}{cc}
\hline HRT & $\mathrm{BOD}_{5}$ value $(\mathrm{mg} / \mathrm{L})$ \\
\hline Initial influent & $12,000 \mathrm{mg} / \mathrm{L}$ \\
HRT 15 days & $7,500 \mathrm{mg} / \mathrm{L}$ \\
HRT 20 days & $2,700 \mathrm{mg} / \mathrm{L}$ \\
HRT 25 days & $1,800 \mathrm{mg} / \mathrm{L}$ \\
\hline
\end{tabular}

BOD value is equivalent with COD value in which the better the process, the lower the BOD value. Based on the test results, $\mathrm{BOD}$ value was still way higher than the 
waste water quality standard of coconut processing industry to be released to the environment. However, HRT of 25 days was the best HRT to reduce BOD value in nata de coco waste anaerobic processing.

\section{OLR Effect on Anaerobic Processing of Liquid Waste}

\section{Initial influent characteristics}

Table 5 shows the results of initial influent characteristics test used in this research.

Table 5. Result of initial influent characteristics test

\begin{tabular}{cccc}
\hline \multirow{2}{*}{ Parameter } & OLR 0.5 & OLR 1.0 & OLR 1.5 \\
& g/L/day & g/L/day & g/L/day \\
\hline COD $(\mathrm{mg} / \mathrm{L})$ & 10,200 & 20,000 & 30,000 \\
$\mathrm{pH}$ & 4.2 & 4.18 & 4.4 \\
$\mathrm{TSS}(\mathrm{mg} / \mathrm{L})$ & 590 & 730 & 740 \\
\hline
\end{tabular}

\section{Effect of OLR variation on COD parameter reduction}

From the test results (Table 5), it can be seen that at OLR $0.5 \mathrm{~g} / \mathrm{L} /$ day the COD removal efficiency value obtained was $61.44 \%$; at OLR $1 \mathrm{~g} / \mathrm{L} /$ day was $62.00 \%$; and at OLR $1.5 \mathrm{~g} / \mathrm{L} /$ day was $50.89 \%$. The results showed that OLR increased up to $1.0 \mathrm{~g} / \mathrm{L} /$ day would increase COD removal efficiency to $62.00 \%$, however, at a further increase to OLR $1.5 \mathrm{~g} / \mathrm{L} /$ day, the COD removal efficiency decreased to $50.89 \%$. This shows that at OLR 1.5 g/L/day, organic overload occurred. Organic overload can cause acidification that makes the condition in the system does not support the methanogenic bacteria growth (Vaccari et al., 2006). If methanogenic bacteria growth is disturbed, the process of organic substance degradation into methane would be disturbed and the process efficiency would decrease (Gerardi, 2003).

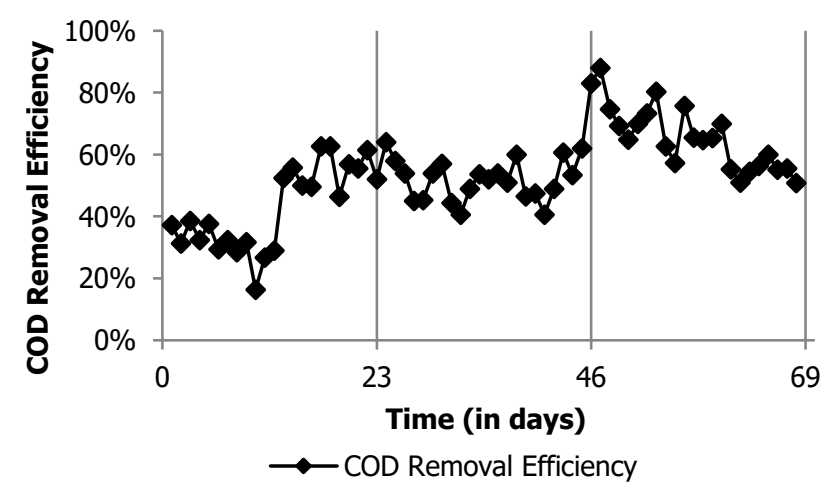

Figure 5. COD removal efficiency in various incubation time

Table 6. effluent COD analysis results

\begin{tabular}{cccc}
\hline $\begin{array}{c}\text { OLR } \\
\text { Variation }\end{array}$ & $\begin{array}{c}\text { COD Influent } \\
(\mathrm{mg} / \mathrm{L})\end{array}$ & $\begin{array}{c}\text { Effluent COD } \\
(\mathrm{mg} / \mathrm{L})\end{array}$ & $\begin{array}{c}\text { COD Removal } \\
\text { Efficiency }(\%)\end{array}$ \\
\hline $0,5 \mathrm{~g} / \mathrm{L} /$ day & 10,200 & 3,933 & 61.44 \\
$1,0 \mathrm{~g} / \mathrm{L} /$ day & 20,000 & 7,600 & 62.00 \\
$1,5 \mathrm{~g} / \mathrm{L} /$ day & 30,000 & 14,733 & 50.89 \\
\hline
\end{tabular}

\section{Effect of OLR variation on TSS parameter decrease}

Figure 7 shows that OLR increased from $0.5 \mathrm{~g} / \mathrm{L} /$ day to $1 \mathrm{~g} / \mathrm{L} /$ day would increase TSS removal efficiency from 59.89 to $75.34 \%$. Whereas when OLR was increased to $1.5 \mathrm{~g} / \mathrm{L} /$ day, TSS removal efficiency decreased to $74.32 \%$. In the previous research (Yi et al., 2014), the increase of total solids content from 5 to $20 \%$ in food waste processed anaerobically will increase volatile fatty acids concentration in the process. In this research, along with the increase of OLR applied, TSS content in the influent also increased, that was, $590 \mathrm{mg} / \mathrm{L} ; 730$ $\mathrm{mg} / \mathrm{L}$ and $740 \mathrm{mg} / \mathrm{L}$, consecutively. Volatile fatty acids is the result of organic molecule degradation from formation stage by acidogenic bacteria. The increase of volatile fatty acids in the process indicates an increase of acidogenic bacteria performance (Deublein \& Steinhauser, 2008). This is what possibly causes the increase of efficiency on the reduction of TSS value when OLR increased up to $1 \mathrm{~g} / \mathrm{L} /$ day. Further increase OLR up to $1.5 \mathrm{~g} / \mathrm{L} /$ day will cause the concentration of volatile fatty acids in the process to become too high and accumulated that it disrupts methanogenic bacteria performance. When the $\mathrm{pH}$ is too low for methanogenic bacteria growth, volatile fatty acids would be accumulated because there is nothing that will be processed further. Bacteria that work in the acid-forming stage will perform optimally at pH 5.2-6.3 (Wikandari, 2014). When volatile fatty acids accumulation in the system causes a decrease in $\mathrm{pH}$ beyond the optimal $\mathrm{pH}$ level, the growth of bacteria that work at the stage of acid formation would be disturbed. Consequently, the performance efficiency of bacteria in the acid-forming stage to hydrolyze suspended solids into simpler monomer would also decrease.

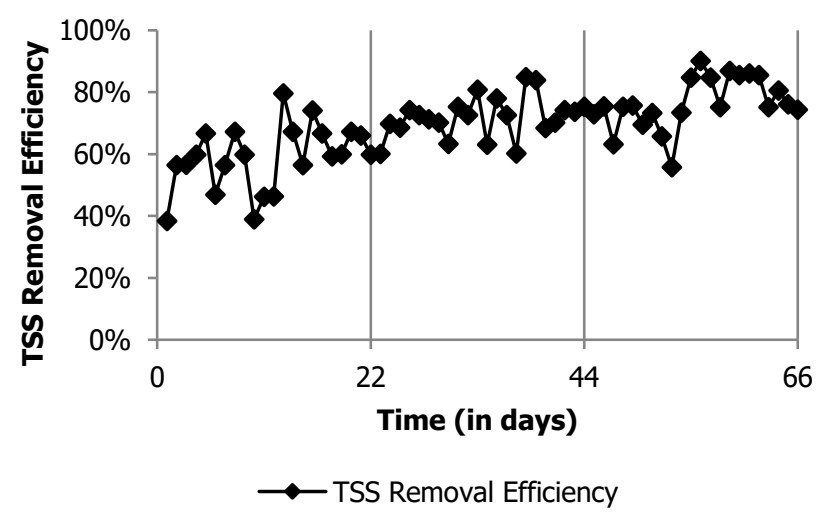

Figure 6. TSS removal efficiency in various incubation time

Table 7. TSS influent and effluent analysis results

\begin{tabular}{cccc}
\hline OLR & $\begin{array}{c}\text { Influent TSS } \\
(\mathrm{mg} / \mathrm{L})\end{array}$ & $\begin{array}{c}\text { Effluent TSS } \\
(\mathrm{mg} / \mathrm{L})\end{array}$ & $\begin{array}{c}\text { TSS Removal } \\
\text { Efficiency }(\%)\end{array}$ \\
\hline $0.5 \mathrm{~g} / \mathrm{L} /$ day & 590 & 236,67 & 59,89 \\
$1 \mathrm{~g} / \mathrm{L} /$ day & 730 & 180,00 & 75,34 \\
$1.5 \mathrm{~g} / \mathrm{L} /$ day & 740 & 143,33 & 74,32 \\
\hline
\end{tabular}




\section{Effect of OLR variation on effluent pH}

Figure 7 shows that effluent $\mathrm{pH}$ at OLR $0.5 \mathrm{~g} / \mathrm{L} /$ day was in the range between 5.58-6.84 and was at 5.74 on the last day of the process. At OLR $1 \mathrm{~g} / \mathrm{L} /$ day, the effluent $\mathrm{pH}$ range was between $4.58-6.1$ and was at 4.59 on the last day of the process. Whereas at OLR $1.5 \mathrm{~g} / \mathrm{L} /$ day, the effluent $\mathrm{pH}$ range was between $3.97-5.75$, and was 4.13 on the last day of the process.

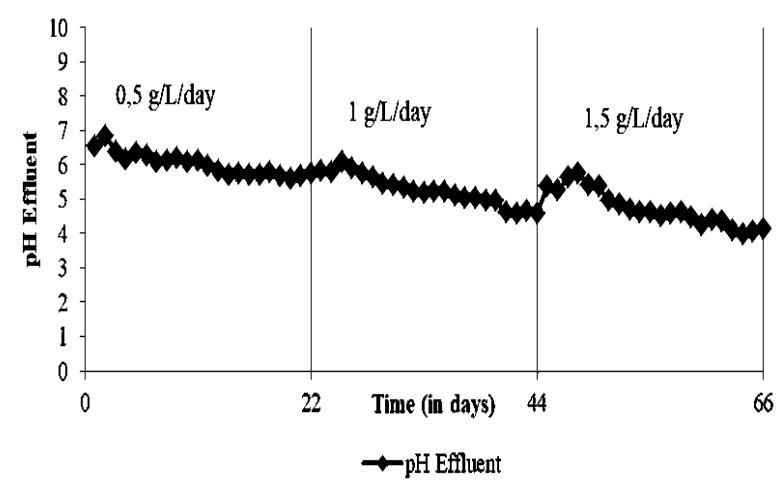

Figure 7. Effect pH at OLR $0.5 \mathrm{~g} / \mathrm{L}, 1.0 \mathrm{~g} / \mathrm{L}$ and $1.5 \mathrm{~g} / \mathrm{L}$

The $\mathrm{pH}$ of effluent decreased along with the increase of OLR. The decrease of $\mathrm{pH}$ is an indication of organic overload. Organic overload occurs when the amount of organic materials fed into anaerobic digester exceeds the total microbial degradation capacity to produce biogas. As the consequence, the organic materials are only partially degraded into volatile fatty acids (VFA), which then accumulate in the digester. If there is VFA accumulation and the concentration exceeds the buffer capacity in the reactor, acidification process and $\mathrm{pH}$ decrease will occur (Drosg, 2013).

\section{Effect of OLR variation on effluent BOD value}

From the research results, it is determined (Table 8) that OLR variation brings similar effect on efficiency of COD and BOD removal.

Table 8. Effluent BOD test results

\begin{tabular}{cc}
\hline OLR & Effluent BOD $(\mathrm{mg} / \mathrm{L})$ \\
\hline $0.5 \mathrm{~g} / \mathrm{L} /$ day & $5,824.70$ \\
$1.0 \mathrm{~g} / \mathrm{L} /$ day & 490.17 \\
$1.5 \mathrm{~g} / \mathrm{L} /$ day & $7,212.00$ \\
\hline
\end{tabular}

Table 8 shows that BOD value decreased when OLR was increased up to $1 \mathrm{~g} / \mathrm{L} /$ day, and then increased again when OLR was increased further to $1.5 \mathrm{~g} / \mathrm{L} /$ day. Based on the result, it is concluded that BOD removal efficiency increased when OLR was increased from $0.5 \mathrm{~g} / \mathrm{L} /$ day to 1 $\mathrm{g} / \mathrm{L} /$ day. However, when OLR was increased to 1.5 $\mathrm{g} / \mathrm{L} /$ day, BOD removal efficiency decreased. This shows that at OLR $1.5 \mathrm{~g} / \mathrm{L} /$ day, organic overload occurred.

\section{CONCLUSION}

Based on the results of this research, it can be concluded that HRT minimal to process nata de coco liquid waste was 20 days. Efficiency of pollutant level reduction would increase along with the increase of OLR up to a certain point. The increase of OLR up to 1.0 $\mathrm{g} / \mathrm{L} /$ day increased COD removal efficiency from 61.44 to $62.00 \%$; TSS removal efficiency from 59.89 to $75.34 \%$; and significantly reduced effluent BOD value from 5824.70 to $490.17 \mathrm{mg} / \mathrm{L}$. However, an increase of OLR to $1.5 \mathrm{~g} / \mathrm{L} /$ day reduced the efficiency of pollutant level reduction caused by the occurrence of organic overload.

\section{ACKNOWLEDGEMENT}

The Directorate of Research and Community Service, the Directorate General of Research and Development Affirmation, Ministry of Research, Technology and Higher Education are gratefully acknowledged for providing the funding for this research through Higher Education Prominent Research Grant (PUPT), Universitas Gadjah Mada, based on research program assignment agreement No. 015/SP2H/LT/DRPM/II/2016.

\section{REFERENCES}

Badan Standardisasi Nasional. (2009). SNI 6968.72:2009: Air dan air limbah - Bagian 72: Cara uji Kebutuhan Oksigen Biokimia (Biochemical Oxygen Demand), 28.

De Mes, T. Z. D., Stams, A. J. M., Reith, J. H., \& Zeeman, G. (2003). Methane production by anaerobic digestion of wastewater and solid wastes. Bio-Methane \& BioHydrogen, 58-102.

Demirer, G. N., Duran, M., Güven, E., Ugurlu, Ö., Tezel, U., \& Ergüder, T. H. (2000). Anaerobic treatability and biogas production potential studies of different agro-industrial wastewaters in Turkey. Biodegradation, 11(6), 401-405. https://doi.org/10.1023/A:1011659705369.

Deublein, D., \& Steinhauser, A. (2008). Biogas from Waste and Renewable Resources: an Introduction. Wiley-VCH.

Drosg, B. (2013). Process Monitoring in Biogas Plants. IEA Bioenergy. $\quad$ Retrieved from https://www.nachhaltigwirtschaften.at/resources/iea_pdf/ reports/iea_bioenergy_task37_brochure_biogas_process_ montoring.pdf.

Rice, E. W., Baird, R. B., Eaton, A. D., \& Clesceri, L. S., editors. (2012). Standard Methods for the Examination of Water and Wastewater, 22nd Edition. American Public Health Association, American Water Works Association, Water Environment Federation. Retrieved from https://www.awwa.org/store/productdetail.aspx?producti $d=28493774$.

Gerardi, M. H. (2003). The Microbiology of Anaerobic Digesters. https://doi.org/10.1002/0471468967.

Hakimi, R. \& Budiman, D. (2006). Aplikasi Produksi Bersih ( Cleaner Production ) Pada Industri Nata De Coco. Jurnal Teknik Mesin, 3(2), 89-98.

Ika (2015). 150 Perajin Nata de Coco DIY-Jateng Kumpul di UGM. Retrieved from https://ugm.ac.id/id/berita/10364150.Perajin.Nata.de.Coco.DIYJateng.Kumpul.di.UGM. [3 
September 2016].

Kim, J. K., Oh, B. R., Chun, Y. N., \& Kim, S. W. (2006). Effects of temperature and hydraulic retention time on anaerobic digestion of food waste. Journal of Bioscience and Bioengineering, 102(4), 328-332. https://doi.org/10.1263/jbb.102.328.

Lestari, A., Ahmad, A., \& Zahrina, I. (2012). Penyisihan Chemical Oxygen Demand ( COD ) Limbah Cair.

Liu, Y. \& Whitman, W. B. (2008). Metabolic, Phylogenetic, and Ecological Diversity of the Methanogenic Archaea. Annals of the New York Academy of Sciences, 1125(1), 171-189. https://doi.org/10.1196/annals.1419.019.

Lukitawesa (2014). Effect of Organic Loading Rate on The Biogas Production of Oil Palm Empty Fruit Bunch in Semicontinuous Anaerobic Digestion. Universitas Gadjah Mada.

Nayenggita, L. (2016). Karakteristik Limbah Cair dari Industri Nata de Coco. Universitas Gadjah Mada.

Okoh, A. I., Odjadjare, E. E., Igbinosa, E. O., \& Osode, A. N. (2007). Wastewater treatment plants as a source of microbial pathogens in receiving watersheds. Journal of Biotechnology, 6(25), 2932-2944. https://doi.org/10.4314/ajb.v6i25.58260.

Peraturan Menteri Lingkungan Hidup Republik Indonesia No. 5 (2014).

Vaccari, D. A., Strom, P. F., Alleman, J. E., \& John Wiley \& Sons. (2006). Environmental biology for engineers and scientists. Wiley-Interscience.

Wikandari, R. (2014). Effect of Fruit Flavors on Anerobic Digestion: Inhibitions and Solutions. University of Boras.

Yi, J., Dong, B., Jin, J., \& Dai, X. (2014). Effect of Increasing Total Solids Contents on Anaerobic Digestion of Food Waste under Mesophilic Conditions: Performance and Microbial Characteristics Analysis. PLOS ONE, 9(7), e102548. https://doi.org/10.1371/journal.pone.0102548. 